\title{
THE ROLE OF SELF-EFFICACY IN WRITING ACHIEVEMENT OF INDONESIAN SENIOR HIGH SCHOOL STUDENTS
}

\author{
Asmaul Husna ${ }^{1}$, Ary Setya B. N. ${ }^{2}$, Galuh Nur Rohmah ${ }^{3}$ \\ ${ }^{1}$ English Language Education IAIN Kediri \\ nanahusna100@gmail.com \\ ${ }^{2}$ English Language Education IAIN Kediri \\ ary_oyesip@yahoo.com \\ ${ }^{3}$ English Liteature Department, UIN Maulana Malik Ibrahim Malang \\ galuh98@bsi.uin-malang.ac.id
}

\begin{abstract}
Writing is one of the productive skills in English learning. This activity can be influenced by another psychological factor, such as self-efficacy. It is a psychological factor that is related to someone's believes in doing something successfully. This research aims at investigating the correlation between self-efficacy and writing achievement. This research uses correlation quantitative as the research design. The participants are 110 students of the tenth-grade students of MAN 1 Kota Kediri. To get data, the instruments used are a self-efficacy questionnaire and writing test. The result of this research revealed that there is no significant correlation between self-efficacy and writing achievement.
\end{abstract}

Keywords: Self-efficacy; writing achievement; correlation.

Self-efficacy, as the psychological factor that can occur during the learning process seems to support the students' writing achievement. The students with high selfefficacy have perseverance in facing the challenge, although they face difficulties in it. They have the confidence to solve the problem and find the best way to deal with it. They believe that if they struggle more, their ability will be better. However, the low selfefficacy students do not have the confidence to go through the challenge. Writing in English is a challenge, especially for Indonesian students. It is because English is a foreign language. Every student will have different reaction in doing it. Some of them may be confident to do it and belief in their own ability, but others maybe not.

Hashemnejad et al., (2014) argued that learners with low self-efficacy levels prefer to choose the task on which there is a possibility to make few errors. They try to do not show their lack ability. Jalaluddin et al., (2015) made a conclusion that someone who has positive self-efficacy in writing will have the potency to continue writing, although it has some challenges. He or she perseveres and will maximize their capability to reach the goal. Thus, a learner will try to find how to solve the writing problems. In doing it, a learner will make some strategies in doing writing. A. Alkubaidi (2014) investigated the students strategy use in writing and showed that they used more strategy in pre writing stage. All of those findings were found in the area of university students who take English subject. So there is no information whether it is will be the same in the senior high school students or not. 
This article is based on some arguments. First, the students' perception of their ability in finishing certain task will affect their subsequent learning growth. It means that the level of students' self-efficacy will have role in how they continue the task, especially in writing, and maximize their effort to reach the goal. Second, in determining learners' communicative effort, self-efficacy is being crucial factor. Because of it, self-efficacy can be one of the concerns when attempting in developing learners' achievement in a foreign language such as in writing activity.

From the description above, this study is used to show the correlation among selfefficacy, writing strategy, and writing achievement of the Senior High School in Indonesia. Furthermore, the result will show how strong the correlation between them. By knowing them, the teachers will have a sight to create the method or strategy in teaching writing, especially in Indonesia. This will help the teachers how to modify the classroom environment and to decide the task that can influence their writing selfefficacy.

\section{LITERATURE REVIEW}

Self-efficacy has been reported as a significant predictor of students' achievement at the different academic level. Majidifar (2015) examined the correlation between anxiety, self-efficacy, and writing performance of Iranian intermediate learners. It revealed that anxiety and self-efficacy have an important role in learners' writing skills. Self-efficacy seems to have a link with the students' success in writing.

Self-efficacy is defined as people's belief in their capabilities to mobilize cognitive resources, motivation, and courses of action needed to exercise control over task demands. In short, self-efficacy is people's confidence in their capability to do a specific action.

The perceived self-efficacy theory shows that someone's self-belief of the capability to do writing will affect his or her subsequent writing growth. The explanation is if individual that holds positive writer selfefficacy will be possible to have desire to continue writing although he or she faces the challenges (Hashemnejad et al., 2014). The tasks include composition, correct punctuation, and creating grammatically correct sentences in writing. According to it, writing in English as a foreign language for Indonesian learners is a new challenge for them.

Bruning et al., (2013) view writing self-efficacy has three dimensions: selfregulation, writing convention, and ideation. Learners' self-regulatory skills are not only used to generate productive ideas and strategies in writing but also be used to manage the emotions during the writing process. The next is writing convention. It refers to the set of accepted standards in general that is for expressing ideas in writing of a given language. The last is ideation. Idea generation can be explained as an ongoing process of memory that influences all other parts of writing. It is related to the belief of the writer about his or her abilities to generate the idea.

Writing is both mental and physical activity. Writing is mental because in writing, the writer invents ideas, thinks about how to put the ideas in, and organizes them in the form of statements in some paragraph. This process aims to make the readers understand what the text is about. There are five aspects of writing. They are content, organization, vocabulary, language use, and mechanics. All of them should be considered to create good writing. Writing is also part of the physical act. The physical act of writing is putting the words or idea into the type of paragraph. It can be in the form of text, message, or letter. So, writing plays both physical act and mental work of students. As a physical act, writing can be called a productive skill. The writing activity will produce a product that is full of ideas from the writer. 
Some researchers conducted research in the field of self-efficacy and students' writing of different level. The study conducted by Hetthong \& Teo, (2013) had aims to explore if self-efficacy predict the writing performance (paragraph level and sub-skill level) of English department students. Another study was conducted by Khosravi, (2017) to examine the link among writing strategies, self-efficacy and writing ability in a case of Iranian students who take a study in English department too. Another study was conducted by Majidifar (2015) that focuses on three variables: self-efficacy, anxiety, and writing performance. It aims to find if there is correlation among selfefficacy, anxiety and writing performance of Iranian intermediate students. The result showed that both self-efficacy and anxiety have role in intermediate students' writing skills. From those previous studies, it showed that self-efficacy has role in the writing performance of English department students and intermediate learners. From this result, the researcher wants to know if selfefficacy has the same influence too in Indonesian senior high school learners, especially in senior high school level.

\section{METHOD}

This research is a correlation study that is used to know if there is a correlation between two or more variables. The variables are students' writing self-efficacy and writing achievement. Self-efficacy is the psychological factor that can affect the writing product. The aim of this research is to find out if there is any correlation between self-efficacy and writing achievement of Indonesian senior high school students. The result will show if the learners with high self-efficacy will have high score in writing too or not, or maybe self-efficacy does not have role in students' writing performance.

The target population in this research is all students at $10^{\text {th }}$ grade in MAN 1 Kota Kediri. They learned English as the subject in their school. The total population is 353 students, and it is from 9 classes. Because of the entire population is too big, the researcher conducted this study on sample size. Sample is the part of the population that represents the whole population because it has certain criteria that will be researched. According to Gay et al., (2012), the minimal sample size for correlation research is 30 subjects. From it, the researcher takes 110 participants as a sample of this research that will represent the whole of the population. They are from four different classes (X MIPA 1, X MIPA 2, X IIS 1, and X IIS 2).

The researcher used some instruments in collecting data and information for answering the research question. The first instrument is the SelfEfficacy for Writing Scale (SEWS) adapted from Bruning et al., (2013) in order to measure students' writing self-efficacy. It is examining three different dimension of writing: ideation, conventions, and selfregulation. The original instrument contains 16 statements. To make sure that this questionnaire can be used for Indonesian learners, the researcher conducted try out. After tried out the instrument to get validity in every questionnaire statement, the final total statement in this questionnaire is 14 statements. It is closed-ended questionnaire and the options can be chosen by giving checklist $(\sqrt{ })$. The scale is from $1-4$, so the total maximum score of students' selfefficacy is 56 and the minimum score is 14 . The researcher tried out the instrument and found that the Cronbach Alpha value of it is 0.802 . It means that the instrument is reliable. The self-efficacy questionnaire also being translated into Indonesia and then asked the expert to check the translation.

The second instrument is a writing task. The learners are asked to compose a recount text in 60 minutes, and the minimum words are 200. Recount text is chosen because the one source of efficacy beliefs is mastery experience. The students had learned about recount text when they were in junior high school. So they are familiar with recount text and how the text is. Recount text was also taught again in the tenth grade. It 
will make them more familiar and have more knowledge about recount text. The learners were given a writing sheet that includes instructions on what they should do. The researcher decided the theme for writing text is "Unforgettable experience". It is used because, based on the researchers' observation, the learners usually read and write the recount text about their holiday, embarrassing moment, and graduation or birthday party. All of those topics are about their experience in the past, so the researcher took the general themes "Unforgettable experience."

In the beginning, the researcher distributed the Self-efficacy for Writing Scale (SEWS) to the students. The researcher explained to them that this questionnaire is about their self-efficacy in writing. They were given instructions to fill the questionnaire based on what they feel faithful and prohibited from imitating others' answer. Then, all of the data from the questionnaire was computed in excel. After that, the researcher conducted a writing test. The researcher delivered the writing sheet for all of the participants and explained the instruction of the test. They did the test in 60 minutes. Next, the result of the writing test is being scored and compute to Microsoft excel.

The results of the writing test are assessed by two raters. To score the students' writing, the scoring rubric from EFL Composition Profile of Jacob et al. was used. The score focuses on five writing aspects. They are the content, organization, language use, vocabulary, and mechanics. Every aspect will be scored in the range 1 to 4 . The total maximum score is 20 , and the total minimum score is 5 . The final writing score is from the average scores from rater 1 and rater 2. The researcher also conducted a reliability test to find out the correlation of writing scores between two raters. The result showed that the value coefficient of the correlation is 0.689 , which means the correlation between the two raters is high. All of the quantitative data is calculated using SPSS 21.0 Statistical Computational Program and Microsoft Office Excel 2016.

The researcher calculates the statistical analysis consisted of a normality test using Kolmogorov-Smirnov. Then, to determine the correlation between two variables in normal distribution, Pearson Product Moment Correlation is used. If the data distribution is not normal, Kendall's Tau Correlation is used as the data processing method. It is to see the correlation between self-efficacy and writing strategy, self-efficacy and writing achievement, and the correlation between writing strategy and writing performance.

\section{FINDINGS}

In answering the research question, the researcher analyzed the data from two instruments. The first is data about the level of writing self-efficacy that was from the self-efficacy question. The second data is from the result of the students' writing task. All of those data were computed and be analyzed to know whether there is correlation between students' self-efficacy and writing achievement or not.

The first thing to do is testing the normality of the data. A normality test is used to know the residual value is distributed normally or not. The normality of the data can be known by using the Kolmogorov-Smirnov test. Both of the data in each instrument are tested, and the result of the normality test is shown below.

Table 1. Normality Test of Self-efficacy Score

Tests of Normality

\begin{tabular}{ccccccc}
\hline & \multicolumn{4}{c}{ Kolmogorov-Smirnov $^{\text {a }}$} & \multicolumn{3}{c}{ Shapiro-Wilk } \\
\cline { 2 - 6 } & Statistic & Df & Sig. & Statistic & df & Sig. \\
\hline
\end{tabular}




\begin{tabular}{lllllll}
\hline $\begin{array}{l}\text { Writing Self- } \\
\text { Efficacy }\end{array}$ & .138 & 110 & .000 & .935 & 110 & .000 \\
\hline
\end{tabular}

a. Lilliefors Significance Correction

Table 2. Normality Test of Students' Writing Score

Tests of Normality

\begin{tabular}{lcccccr}
\hline & \multicolumn{3}{c}{ Kolmogorov-Smirnov $^{\mathrm{a}}$} & \multicolumn{3}{c}{ Shapiro-Wilk } \\
\cline { 2 - 7 } & Statistic & Df & Sig. & Statistic & df & Sig. \\
\hline $\begin{array}{l}\text { Writing } \\
\text { Achievement }\end{array}$ & .101 & 110 & .008 & .961 & 110 & .002 \\
\hline
\end{tabular}

Table 1 and Table 2 show the normality test of self-efficacy and students' writing scores. According to Sunjoyo et al. (2013), the data is normally distributed if the residual number of significance number (sig.) is higher than 0.05 and. From both the result of the normality test, the data of selfefficacy and writing score are not normally distributed. It is because the result of normality test from self-efficacy data is 0.000 and from writing score is 0.008 .

Because of the distribution of the data is not normal, the researcher uses Kendall's Tau correlation to calculate the correlation. Here is the result of the correlation between students' writing self-efficacy and students' writing achievement.

Table 3 Correlation between Self-efficacy and Writing Achievement Correlations

\begin{tabular}{lllr|r}
\hline & & Self-efficacy & $\begin{array}{c}\text { Writing } \\
\text { Achievement }\end{array}$ \\
& & Correlation Coefficient & 1.000 & .066 \\
& Self-efficacy & Sig. (2-tailed) &. & .357 \\
& & $\mathrm{~N}$ & 110 & 110 \\
Kendall's tau_b & & Correlation Coefficient & .066 & 1.000 \\
& Writing & Sig. (2-tailed) & .357 & 110 \\
& Achievement & $\mathrm{N}$ & 110 \\
& & & & \\
& & & &
\end{tabular}

Significance value is used to decide what hypothesis is accepted. Priyatno (2018) states Ho is accepted if the significant value is greater than 0.05 ( $\mathrm{Sig}$. 2-tailed>0.05), and $\mathrm{Ha}$ is accepted if the significant value is obtained $\leq \alpha=0.05$. Based on the table above, the sig. 2 tailed is 0.357 , which is greater than 0.05. It means that Ho is accepted and it can be concluded that there is no significant correlation between them.

From the table above, the coefficient correlation is $0.066(\mathrm{r}=0.066)$. It indicates that the correlation between self-efficacy and writing achievement is very low or very weak. The attribute of the correlation coefficient shows that it is a positive correlation. It indicates that students' writing self-efficacy affects the students' writing achievement.

\section{DISCUSSION}

In the previous part, the result shows that there is no significant correlation between self-efficacy and writing achievement. It is because the significance value is greater than 0.05 , which shows the number 0.35 . Ho cannot be rejected if the significance value is greater than 0.05 . 
The result of this study is in contrast with some previous studies. The first study is conducted by Khosravi (2017). They found that there is a significant correlation between self-efficacy and writing performance. They believe that an increase in self-efficacy would increase students' writing ability and having good score in writing will increase students' self-efficacy. Other research was done by Majidifar (2015) The result of their study shows that there is strong correlation between self-efficacy and writing performance. The coefficient correlation of it is 0.722 .

The result is in line with the study that was conducted by Hashemnejad et al., (2014). They are examined the relationship between students' self-efficacy and writing performance across gender. The result shows that there is no significant relationship between male and female's self-efficacy and writing performance. They distributed the self-efficacy questionnaire three times to ensure the consistency of the participants self-efficacy score. The result of the three times delivering questionnaire revealed the same conclusion, that there is no correlation between self-efficacy and writing performance through male and female. This result also same with the study conducted by Khojasteh et al. (2016) It shows that there is no any significant correlation between male and female participants' self-efficacy and writing performance. The study conducted by Chea \& Shumow, (2015) also showed that writing self-efficacy does not significantly predict students' writing achievement. Moreover writing goal orientation also does not have any correlation with students' writing.

The different result of this study with other can be caused by some factors. According to Lemeshow in Sadik (2014), some factors that can affect the variable in the correlation study are the measurement used, the person who be the participant, and the object being measured. The participants of previous studies are University students, and the participants of this study are senior high school students. In Indonesia, English is not as the main course. There are more than ten subjects that senior high school students should follow. In their English subject, writing is not the main focus. There are reading, listening, speaking, and grammar. In the previous study, the participants of the study are the students who take the class focus on English. They also take more focus on writing. Another factor that can affect the result of this study is students' writing strategy. Nasihah \& Cahyono (2017) stated that the more frequently the students use language learning strategies, the higher their writing score and vice versa. It is because the students with high self-efficacy level will use more writing strategy (Khosravi, 2017) These reasons are the possibility that makes the result is different with the previous study.

Based on the explanation above, this study suggests the teachers to explain some strategies that can be used in a writing activity. The appropriate writing strategy used will make them have a better writing product. If the students' writing product is better, it will increase the students' selfefficacy level. It is because one of the sources of efficacy belief is mastery experiences.

Based on the result, the researcher suggests that students' self-efficacy beliefs cannot be ignored. It will make them confident in finishing the task given. What the teacher can do is to increase and support their self-efficacy beliefs by teaching them how to write good paragraph. Teacher should explain them some strategies that can be used in every stage of writing such as prewriting, writing and revising.

\section{CONCLUSION}

The finding of this study did not show that there is a correlation between selfefficacy and writing achievement. It is not in line with some previous studies that said students' self-efficacy correlate with their writing achievement. The result also did not 
the same as the arguments in the previous. It is stated that the learners' belief of their ability to complete certain task will affect the learning growth. The students' self-efficacy in writing has role in how they continue the task and how to maximize the effort to reach the goal. The result showed that students' self-efficacy levels do not correlate with their writing achievement. Another statement in the previous is self-efficacy is a crucial factor in determining communicative effort. From the result, it can be concluded that selfefficacy cannot be the only factor that can develop learners' writing achievement.

The method and instruments used in this study can answer the research question. By having the data of students' self-efficacy level and writing achievement, the researcher can examine if both of the variables are correlated with each other or not. Although the result is different from the arguments showed in the previous, but this research offers the conclusion that there are other factor or reason which will affect and correlate with students' writing achievement. The teachers should pay more attention and train the students' to have more practice and efficient strategy in the writing. It is because their confidence in doing the task can be a predictor that they can be successful in writing.

This research raises the important question about what are other factors that can contribute to writing and students' selfefficacy. As a result of this study, the researchers suggest to other researchers to conduct more research in self-efficacy and combine it with other psychological factors that can affect students writing achievement. The other psychological factors that can be researched are anxiety, motivation, and self-esteem. The future research also can conduct a study about how are the Indonesian learners' strategies in doing writing activities. It will give more information about other factors that have contribution or not in writing.

\section{ACKNOWLEDGEMENT}

The authors would like to present the gratitude to some participants of the research and big thanks to reviewers and editors for making this paper better by giving some constructive feedback

\section{REFERENCES}

A. Alkubaidi, M. (2014). The Relationship between Saudi English Major University Students' Writing Performance and Their Learning Style and Strategy Use. English Language Teaching, 7(4), p83. https://doi.org/10.5539/elt.v7n4p83

Bruning, R., Dempsey, M., Kauffman, D. F., McKim, C., \& Zumbrunn, S. (2013). Examining dimensions of self-efficacy for writing. Journal of Educational Psychology, 105(1), 25-38. https://doi.org/10.1037/a0029692

Chea, S., \& Shumow, L. (2015). The Relationships Among Writing Self-Efficacy, Writing Goal Orientation, and Writing Achievement. Language Education in Asia, 5(2), 253-269. https://doi.org/10.5746/LEiA/14/V5/I2/A07/Chea_Shumow

Gay, L. R., Mills, G. E., \& Airasian, P. W. (2012). Educational research: Competencies for analysis and applications (10th ed). Pearson.

Hashemnejad, F., Zoghi, M., \& Amini, D. (2014). The Relationship between Self-efficacy and Writing Performance across Genders. Theory and Practice in Language Studies, 4(5), 1045-1052. https://doi.org/10.4304/tpls.4.5.1045-1052 
Hetthong, R., \& Teo, A. (2013). Does Writing Self-efficacy Correlate with and Predict Writing Performance? International Journal of Applied Linguistics \& English Literature, 2(1), 157-167. https://doi.org/10.7575/ijalel.v.2n.1p.157

Jalaluddin, I., Paramasivam, S., Husain, S., \& Bakar, R. A. (2015). The Consistency between Writing Self-efficacy and Writing Performance. Journal of Language Teaching and < | 58 Research, 6(3), 545. https://doi.org/10.17507/jltr.0603.09

Johnson, B. \& Christensen, L. (2014).Educational Research: quantitative, Qualitative, and Mixed Approaches. London: SAGE Pyblications.

Khojasteh, L., Shorkpour, N., \& Afrasiabi, M. (2016). The Relationship between Writing Self-efficacy and Writing Performance of Iranian EFL Students. International Journal of Applied Linguistics and English Literature, 5(4). https://doi.org/10.7575/aiac.ijalel.v.5n.4p.29

Khosravi, M. (2017). The Relationship between Writing Strategies, Self-Efficacy and Writing Ability: A Case of Iranian EFL students. Translation Studies, 05(03), 7.

Majidifar, S. (2015). The Relationship among Test Anxiety, Self-Efficacy, and Writing Performance Among Iranian Intermediate EFL Learners. International Journal of Language and Linguistics, 3(6), 323. https://doi.org/10.11648/j.ijll.20150306.11

Nasihah, M., \& Cahyono, B. (2017). Language Learning Strategies, Motivation, and Writing Achievement of Indonesian EFL Students. Arab World English Journal, 8(1), 250-263. https://doi.org/10.24093/awej/vol8no1.18

Nunan, D (2013). Pracatical English Teaching, New York: McCraw. 